\title{
A cosmopolis of all beings: Cosmopolitanism, indigeneity, and the more-than-human
}

\author{
Una cosmopolis de todos los seres: \\ Cosmopolitismo, indigeneidad, y más que lo \\ humano (el mundo no humano)
}

\author{
Une cosmopolis de tous les êtres: \\ Cosmopolitisme, indigénéité, et le plus \\ qu'humain
}

\section{Chris Beeman}

Brandon University, Canada

\begin{abstract}
Cosmopolitanism - either an idea that goes far back in recorded human history, or an approach whose form came before a definition - places high value on individual moral responsibility to other moral beings beyond the intermediation of the nation-state. Nussbaum's version links cosmopolitanism to rational liberal democracy, but not to the utter exclusion of individual loyalty to the state. Appiah's more nuanced version still holds the possibility of a universalist ethic while respecting difference. Magsino sees cosmopolitanism as a possible countervailing force to globalization. All of these recent theorists place cosmopolitanism in the realm of human action and responsibility. This paper explores Spinoza's philosophy as a route into broadening the sphere of cosmopolitanism to the more-than-human world. In doing so, I note that this shift entails altering the basis of membership therein from one of responsibility to other moral beings, to one of a responsibility to act morally to all beings. This stretches the hitherto human orientation of cosmopolitanism, extending responsibility to other beings even if they do not have ethical responsibility to people. Toulmin's etymological exploration of the word links human ordered-ness to ordered-ness in the world. Spinoza's cosmology is shown to have relevance to some Indigenous ways of being in the world.
\end{abstract}

Key Words: cosmopolitanism; indigenous ontologies; indigeneity; Spinoza's cosmology and indigenous ontologies. 


\section{RESUMEN}

El comopolitismo - sea esta una idea que va lejos en la historia humana escrita, o sea un enfoque cuya forma viene antes que una definición - da un valor muy alto a la responsabilidad moral individual hacia otros seres morales de la intermediación del estado-nación. La versión de Nussbaum relaciona el cosmopolitismo a la democracia liberal racional pero sin excluir la responsabilidad individual y la lealtad al estado. La versión más matizada de Appiah todavía mantiene la posibilidad de una ética universalista con respecto a la diferencia. Magsino ve al cosmopolitismo como una posible fuerza de compensación a la globalización. Todas estos teóricos recientes ubican al cosmopolitismo en el dominio de la acción y la responsabilidad humana. Este artículo explora la cosmología de Spinoza como una manera de no solamente ampliar la esfera del cosmopolitismo a un mundo que incluye más que lo humano, pero al hacer esto cambia las bases de la membresía, moviéndose de la responsabilidad a otros seres morales a actuar moralmente en la medida de la capacidad que uno tiene para desarrollar una sensibilidad moral. Esto amplifica la orientación humana del cosmopolitismo. Sin embargo la etimología de Toulmin que relaciona el ordenamiento humano al ordenamiento en el mundo, sugiere otra cosa. Se muestra aquí que la cosmología de Spinoza tiene relevancia para algunas ontologías indígenas.

Descriptores: cosmopolitismo; ontologías indígenas; indigenismo; la cosmología de Spinoza y las ontologías indígenas.

\section{RÉSUMÉ}

Le cosmopolitisme - ou bien une idée qui remonte loin dans l'histoire humaine écrite, ou bien une approche dont la forme est apparue avant la définition - met beaucoup de valeur sur la responsabilité morale individuelle envers les autres êtres moraux au-delà de l'intermédiation de l'état-nation. La version de Nussbaum lie le cosmopolitisme à la démocratie libérale rationnelle, au-delà mais non pas à l'exclusion de la responsabilité individuelle et la loyauté envers l'état. La version plus nuancée d'Appia conserve la possibilité d'une éthique universaliste tout en respectant la différence. Magsino voit le cosmopolitisme comme une force possiblement en sens contraire s'opposant à la globalisation. Tous ces théoriciens récents placent le cosmopolitisme dans le domaine de l'action et de la responsabilité humaine. Ce papier explore la cosmologie de Spinoza, non seulement comme une voie pour élargir la sphère du cosmopolitisme au monde plus qu'humain, mais aussi, en ce faisant, pour déplacer la base du membership ci-inclus, de la responsabilité aux autres êtres moraux à l'agir moral jusqu'où chaque être est capable de formuler la sensibilité morale. Ceci étend l'orientation humaine du cosmopolitisme au-delà de sa limite actuelle. Mais l'étymologie de Toulmin qui lie l'ordre humain à l'ordre dans le monde en suggère autrement. La cosmologie de Spinoza se révèle pertinente pour certaines ontologies indigènes.

Mots clés: le cosmopolitisme; les ontologies indigènes; I'indigénéité; la cosmologie de Spinoza et les ontologies indigènes.

\section{Introduction}

OSMOPOLITANISM CAN BE VIEWED AS AN IDEA WITHOUT A BEGINNING. In the history
of Western thought, the beginnings of ideas are given special status and are fre-
quently recorded and traceable. While there are nominal ones in this case (Nussbaum,
1994, p. 3) I argue - to some extent, in the company of Kwame Anthony Appiah -
that an expectation of some kind of moral shared-ness based on, rather than in spite
of, difference, is part of a long history of humankind that goes way back to before
"beginnings" (Appiah, 2006, p. xx). Thus, to attempt to trace the ancient origins of 
the tradition that is as basic as the underpinnings of homo sapiens serves little function except as a teaching story.

However, in recent thought, there have been some landmark works, and many responses, on the subject. Toulmin, in his 1990 Cosmopolis, began the most recent phase of re-exploration of the idea. Martha Nussbaum's 1994 essay, "Patriotism and Cosmopolitanism," written for the Boston Review, was widely read and provoked strong responses, many of which were reprinted with the initial paper. More responses were printed in a later book edition of the essay. And Appiah's 2006 monograph, Cosmopolitanism, continues the story, more flexibly and with less necessary reliance on a centrist, democratic, individual, and rational ideal than Nussbaum, but nonetheless, selon Nussbaum, with an eagerness to establish a universalism to the notion of moral responsibility - a higher good than the nation-state.

Following in the footsteps of recent interpreters, the term cosmopolitanism has come to refer to a movement that places moral responsibility on individual people, above and beyond their responsibility to the nation-state. That this should have been such a surprise in late-twentieth century America - as witnessed by the strong response to Nussbaum's essay - is perhaps the most surprising thing about it. By this, I do not only mean that the rampant turn American nationalism has recently taken, justifying publicly what used to be secret sins - the murder of political opponents and the torture of known innocents - would tend to oppose a movement that might challenge its own jingoism. I mean also that one might reasonably expect, in a country which so publicly espouses religion, that the concept of moral responsibility, to at least a God - leaving aside for the time being a moral responsibility, to other people as people - would be readily and consciously adopted. But perhaps the kind of religiosity and moralisticism so publicly announced in America has little to do with morality.

In what I am about to say here, I will not be looking in some very obvious places. For example, I will not be looking at the relevance of Gotama Buddha's reflections on the interconnectedness of all things. I think the case of the interconnectedness of being is well-established experientially in the practice of Buddha's form of meditation, Vipassana, even if it were not established in his discourses. But it is a different kind of case I wish to make in this paper. Here, I wish to push thought qua thought, paying attention to thinkers normally considered marginal to Western philosophy, and to some Indigenous Elders also, but still arriving at conclusions that expand the notion of cosmopolitanism.

In this paper, I wish to make the case for expanding the notion of what constitutes the cosmopolis past the human. I base this on ideas around the notion of being itself, rather than the standard moral case made by Nussbaum and Appiah, and critiqued by various others, which roughly directs individual moral responsibility in cosmopolitanism to other people. I do this by using the views of one Western philosopher - Spinoza - and several Indigenous Elders of my acquaintance, to argue for a different worldview that could be considered, if there were willingness to stretch the term a little, cosmopolitan. By making the case this way, I sidestep the flaw evident in all major arguments, mostly ignored by Nussbaum and incompletely argued by 
Appiah, of how to solve moral disagreements between incompatible groups. While this route has its own obvious shortcomings - most people want to talk of issues relating to people, for example, and cannot conceive of actually being part of a wider conception of community than the human - it has clear roots in the way the notion of cosmopolitanism has historically been used. I rely on Toulmin's often-overlooked Cosmopolis for this case. Both strands of the argument arrive at similar solutions: a cosmopolitanism of all beings.

\section{On Cosmopolitanism Past}

Let me pass over, for the most part, the really famous early work directly related to cosmopolitanism, barely glancing back over my right shoulder at highway speed, as it were, to note a passing silo. I do so because of my own ignorance of them, because the residue of their thought lies in some of the current theorists whose work I will address, and because my current interest in this paper lies in seeing if it is possible to push the conceptual boundaries of the term as it has come recently to be known.

I note in passing the Greek Cynic Diogenes' famous quotation, "I am a citizen of the world." Although I am unable to find the original quotation in Greek, Google Translate gives this in transliteration as "Eimai politis tou kosmou." Thus did cosmos and polites - the world and citizen - become linked in one idea. The Stoics took up this attitude of an ever-widening moral responsibility, using the image of concentric circles of affiliations, ranging from the personal to the (human) universal (Nussbaum, 1994, p. 2). This was a radical notion at the time of Greek city-states, when identity was largely defined by one's belonging to a particular locale and people. Though Diogenes' words date from the fifth century BCE, they are rarely linked to the thought and teachings of Gotama Buddha, who lived only a little earlier. A central premise of Buddha's teachings is the interconnectedness of all beings - both in the human and more-than-human realms.

I also give only a nod here to the contributions of Immanuel Kant to the idea. In addition to a direct address of cosmopolitanism, Kant's categorical imperative itself necessitates a universal orientation of moral stance. The effect of such theorizing has notable later expressions in such documents as the 1789 Universal Declaration of the Rights of Man, and, in the mid-twentieth century, the United Nations' Universal Declaration of Human Rights (Johnston, 2012, p. 7). Johnston also remarks, though, that there are other models of international relations based on non-dominant understandings of cosmopolitanism that rely not on individual moral responsibility, but instead emphasize social justice based on Critical Theory (p. 8).

\section{On Cosmopolitanism Current On Nussbaum, Appiah, Magsino}

I begin with a more detailed discussion of Nussbaum and Appiah, (and later, of 
Rómulo Magsino), both because their work has been so influential, and because their ideas appear to be different interpretations of a similar project. The too-often overlooked work of Toulmin, Cosmopolis, is a much more encompassing project more closely linked to my own, and comes later.

Nussbaum's 1994 paper, "Patriotism and Cosmopolitanism," attempts to establish that cosmopolitanism ought to be pursued over patriotism because only the former permits us "to give our first allegiance to what is morally good - and that which, being good, I can commend as such to all human beings" (p. 2). Cosmopolitanism is an inherently moral stance, one requiring our highest obligation not to a nationstate, but to other people, regardless of their nationality. Hers is a response to Richard Rorty's own op-ed piece in The New York Times (February 13, 1994), in which Rorty espouses the emotion of patriotism in opposition to the "politics of difference" (Nussbaum, 1994, p. 1).

Leaving aside a contextualization of Rorty's essay within his larger life-project that, at the time of its publication, gave further evidence of his shift from the linguistic turn of analytic philosophy, through American Pragmatism, and into American identity and politics, Nussbaum's response appears to represent a broader base for moral responsibility. While Rorty focused on the cooperative advantages of patriotism to avoid the pitfalls of a nation-state fragmented, in his view, by racial, religious, and ethnic difference, Nussbaum's response reminds us that there can be a higher good than the smooth functioning of democracy, and that this good is premised on a consideration of the welfare of all people.

Nussbaum's possibly too optimistic stance is critiqued by Naseem and HyslopMargison (2006). They rightly note that the source of agreement amongst Nussbaum's prospective cosmopolites is liberal reason and rational reflection, housed in a democratic framework. Apart from the obvious concern that, under the guise of protecting difference, such a view might actually promote American interests, Naseem and Hyslop-Margison comment that well-functioning cultures might have very different values and systems in play that organize, compare, and work out differences, differently. In addition to this, a more subtle philosophical point is that such a stance does not promote optimal difference - that is, within her own theory of the value of cosmopolitanism, a broader view of cosmopolitanism fails to take hold.

And there is another way to respond. The sticking point for Naseem and HyslopMargison is human difference: racially, socio-economically, and historically. The roots of the kinds of choices Nussbaum considers possible in a cosmopolitan framework are so different that it is impossible to predict whether, when choices are made from different cultural and epistemic stances, they can or ought to concur ( $\mathrm{p}$. 58). Later in this paper, I propose both a more encompassing and much less easilydismissed route: to use the being that is in all things as the basis of morality, rather than to emphasize individual moral responsibility to others accorded moral status.

Meanwhile, in Cosmopolis, Kwame Anthony Appiah's casual and elegant style cloaks serious philosophical thought. Appiah wishes to preserve not merely the value of difference, but also the long tradition of the accommodation of differences between peoples. After recounting some of the effortlessly cosmopolitan interactions of 
his youth, he writes: "Still, a world in which communities are neatly hived off from one another seems no longer a serous option, if it ever was. And the way of segregation and seclusion has always been anomalous in our perpetually voyaging species. Cosmopolitanism isn't hard work; repudiating it is" ( $\mathrm{p} . \mathrm{xx})$. Despite the naturalness and necessity of preserving difference within political bodies, Appiah claims that certain values both are and should be universal (p. xxi). And yet, there sometimes occur circumstances in which broad obligations to others might compete with obligations to particular people (p. xv).

The bulk of Appiah's project amounts to establishing the moral underpinnings that would make cosmopolitanism possible - that is to say, balancing universalist values with the need to treat individual people as people. This entails, in part, contesting the relativism that emerges from positivism. Appiah represents positivism as a philosophical system in which fact and value are separate. In this version, because only facts occur in response to real things in the world, and because values are not checkable against the world, there is nothing factual about a value; there is nothing to say in a conversation in which the values of two people do not concur. Thus, the prompt outcome of a positivist world view is moral relativism.

While Appiah's book length and nuanced approach leaves more room for variation than Nussbaum's, Naseem and Hyslop-Margison point out that where Appiah's project falls short is in establishing just how differences between a universalist motivation and protection of individual difference play out. Saying that something ought to occur, and showing that, despite intellectual impediments, it can occur, are two different things.

I have grouped Nussbaum and Appiah together because both attempt to link cosmopolitanism to a universalist ethic. Nussbaum does so based on a liberal democratic rational model. Appiah's system is far more nuanced, but is still based in moral values that are sometimes universal. Magsino's work proposes using cosmopolitan ethics in education to resist corporate globalism.

Rómulo Magsino's 2007 essay, "Globalization and Education in the 21st Century," sees Nussbaum's and Held's (1999) positions as useful in educational contexts. His paper notes how cosmopolitanism might be useful in providing an alternate pole to global capitalism. In particular, Magsino notes that while critical pedagogues have brought forward an important challenge to the globalization-influenced public educational policy, they have failed to influence a large enough group of teachers to have any broad effect on public education.

This case has some merit. Certainly both Appiah and Nussbaum see the need in education for an open-minded exploration of difference through a cosmopolitan lens. Both also see the need for the contextualization of such difference within value systems that contain some non-negotiable points of universal application. Given the initial critique of global capitalism that Magsino makes, it would appear that there are certain values that global capitalism transgresses that could be addressed, educationally, in practices rooted in cosmopolitanism.

The point of this brief recounting of these more recent thinkers is to note that, 
while there has been much to conceptually hold the concept together, there is perhaps as much pulling it apart. There is a weak gravity here, weak in the way the outer planets are held together in the form of planets. Were you to step in the stuff of the planet Cosmopolis, it would feel far more like Saturn than Mars. I am encouraged by this. Were a philosophy of difference agreed upon by all of its theorists, I would find the theory suspicious.

\section{On Toulmin}

Despite having an identical title, Stephen Toulmin's project, Cosmopolis, which initiated recent interest in the subject, is quite different in orientation to those of both Nussbaum and Appiah. Toulmin is concerned with the very basis of the project, which he sees going back to a sixteenth-century humanism, as expressed in the Essais of Michel de Montaigne. Such a humanism quickly became overshadowed by the need for intellectual certainty during the brutal Thirty Years' War, after the assassination of Henry IV (de Navarre).

Because Toulmin's endeavour to understand the term is so useful, I follow his argument quite closely. Toulmin's stance was contrarian at the time it was written. Toulmin (1990) states that few had contested the commonly-held view that the late sixteenth and early seventeenth centuries were times of more-or-less continuous economic expansion and social and religious tolerance. In Cosmopolis, Toulmin makes the case that the overturning of sixteenth-century humanism by the "new philosophy" of the seventeenth, characterized by the work of Rene Descartes, represented both a defensive search for certainty at the time of a brutal and destabilizing Thirty Years' War, and a retraction of earlier movement toward a more cosmopolitan intellectual stance as represented by Montaigne. He finds historical evidence for this, especially in the assassination of the tolerant - and still beloved - Henry IV of France, and the several decades of instability after the time of his death. He even proposes a possible first-published work of a young Descartes that links, Donne-like, personal tragedy with atmospheric and cosmological disturbance (Toulmin, 1990, p. 63). Toulmin argues that the history of philosophy would have been quite different, had the flexible humanism of Montaigne not been eclipsed by a Cartesian quest for something - anything - stable, in a time of such political crisis and perceived threat. One need only look to a decade ago for shockingly similar retrenchment in popular culture and thought in North America.

Stephen Toulmin's parsing of the term Cosmopolis is more revealing than other accounts I have noted. Toulmin traces the origin of the term to its two major roots, cosmos and polis, but he does so on both human and natural grounds (pp. 65-69). Both terms refer to a kind of order. The universe without order was ouranos. But when there was order, it became cosmos. And in the realm of human order, polis applied. While the order ascribed to cosmos was certainly structured materially, it was more apparent in the order in which things happened. Seasons progressed, and sun, moon, and heavenly bodies moved in predictable, orderly ways. Tides ebbed 
and flowed, and animals and plants grew, matured, reproduced, and died, all under the direction of the longer cycles of the heavenly bodies. Seasonal winds, such as the yearly Scirrocco ("the wind [that] is in from Africa," à la Joni Mitchell, I assume, to give an example geographically proximate to the term's mythical origins), permitted or restricted travel. All of these were evidence of what has more recently been affirmed, in such theories as Lovelock's Gaia (1972), that what appear to be disparate Terrestrian activities are inextricably linked in an organic whole.

That there is order means that intelligent humans could interpret and experiment in ways that other animals appear less capable of doing. Early humans needed to do this. Some paleo-anthropologists claim that the early modern human capacity to respond to rapid climate change at times about two million years ago, and again, about 200,000 years ago, was a major factor in determining which of several homo strains would survive (Potts, 2012). In other words, the capacity to see patterns and order - in, for example, tidal movement and weather - might have been contributing survival knowledge for early homo sapiens. Recent DNA data suggest that the total number of direct homo sapiens ancestors might have been a very few individuals. It might be reasonably claimed, then, that a capacity to see the possibility of order is a regularly shared human trait. Human capacity to comprehend what order there was in the more-than-human was partly expressed in human success in keeping alive and thriving. Certainly, the interpretation of cosmological cycles still affects agriculture. Meteorologists today acknowledge a new kind of order ignored earlier: the role of surface solar activity on decades-long climatic Earth-bound cycles. The point at issue is simply this: that human capacity to interpret and exploit natural order might be an inherent part of being a person, and that - much in the same way Toulmin proposes - human interpretation of natural order (cosmos) and human-created ordering (polis) might be parts of the same whole.

The second kind of order that Toulmin notes, a human political one, is called polis. Under this kind of order, collective human enterprises in Ancient Greece were conducted. Governance, agricultural cooperation through such projects as irrigation systems, and other shared endeavours were considered part of this kind of order. Something was considered a polis only when it achieved enough shared organization to justify the term. Cosmopolitanism connects human organization through polis with the more-than-human organization in the cosmos. Order in the natural world and order in the world of human society are combined in one term. In this view also, it is possible to see Diogenes' original statement quite differently than it is now interpreted. If Toulmin's rendering is accurate, then Diogenes' statement is a melding of both the human and more-than-human. Perhaps at the time he uttered it, it was much more of a challenge to the polis-centred audience he spoke to than is now recognized.

I find Toulmin's etymology helpful. Other explanations of the term, by Nussbaum and Appiah, simply unite what appear to be aspects of a human-centred whole. Cosmos is usually translated as world and polis as citizen, so Diogenes' statement reads as his being a citizen of the world. This is hardly the complex view expressed in Toulmin. In his analysis, natural and human forces of organization meet at one complex nexus 
between human order and order in the more-than-human world.

Two questions emerge: to what extent did the "orderliness" of nature cause the "polis-ness" of humans? And, to what extent did the occurrence of people cause ouranos to become cosmos? In other words, to what extent does the orderliness of things lead to the capacity to see order? And to what extent does the capacity to perceive order lead to the apparent orderliness of things? It is possible that the response to the former questions, as I have illustrated, is a species-survival one. The obvious response is that perceivers are required for orderliness to occur. Yet, there is something in the way things seem to happen - the claims of social ecologists notwithstanding - that suggests that whether humans were here to see the evidence or not, something like an order would be theoretically capable of being perceived. Thus, the idea of human order, itself, might well be less a product of the structure of mind, than of the world the mind finds itself immersed in.

\section{A New Idea of Cosmopolitanism}

There is a more pertinent supporting case for Toulmin's consideration of cosmopolis, both because of its historical placement and its intellectual orientation: the thought of Baruch Spinoza. The "blessed Spinoza's" sometimes baffling writings evince the difficult circumstance of a displaced person, originally Jewish and later anathematized from his own, already persecuted religion, and forced by circumstance to write in a language not his own. They also express the condition of one whose tolerated existence in the tolerant contemporary city of Amsterdam nonetheless occurred within a broader time and context of extreme vulnerability when one expressed difference. Further, Spinoza's use of the "synthetic" method of reasoning made for a sometimes strained marriage between a rationalist approach and cosmologically holistic ideas. What could be a more ideal circumstance for the emergence of a thinker with sometimes subtle, sometimes novel, and sometimes revolutionary ideas on the nature of God, the universe, and the cosmos within which humans find themselves placed?

Spinoza's probable date of birth, within a decade of Descarte's Meditations, immediately places him as a child of a Rationalist era. His work, too, takes the form of Rationalism. But it was Spinoza's gift to use Rationalist precepts and "technology" patterns of argument - to achieve revolutionary results. Spinoza used the same tools of intellectual construction as Descartes; the same concepts used by the Scholastics - substance, modes, and attributes - were all in play, but from their initial definitions disruptively new conclusions were reached. But to understand Spinoza, we have to go back a little, and again we are invited into the sixteenth century.

Toulmin largely attributes the sixteenth century's different intellectual climate to the changing social and political context of Europe. At Montaigne's time, for example, religious tolerance was greater and the collective European economy was healthier. Toulmin argues that, in a time of economic plenty, there was less need for philosophical certainty. So, when Montaigne wrote that "unless some one thing is 
found of which we are completely certain, we can be certain about nothing" (Toulmin quoting Montaigne, 1990, p. 42) he was supposing that no such thing could be found, and thus he was supporting the case for a tentative, skeptical, humanist response. But in the troubled times when Descartes responded, some fifty years later, this same statement had the sound of a challenge. In response, there was nothing for Descartes to do but search for that source of certainty. That which could ground all thought in certainty was, in fact, thought itself. Thought established the existence of some thinking being - and a benevolent God underwrote it. It is possible that the intellectual vacuum left by a highly original thinker with less propensity to arrive at universal solutions than Descartes was naturally filled by Spinoza.

Spinoza used the tools of Cartesian Rationalism, combined with the terms used by the earlier Scholastics, to arrive at a very different view of the world - the cosmos. Descartes used these same terms: substance, attributes, modes. For Spinoza, there was only one substance. Because there was only one substance, to speak of each object as having an attribute that distinguished it from other objects, as earlier theorists had done, made no sense. There really was only one thing to talk about, although it had the appearance of many different things. What we would commonly think of as different things - trees, groundhogs, cars, and the concept of entelechy, for examples - Spinoza called modes. Under a Spinozean view, things that seem to be separate are actually reflecting aspects of the underlying unity of All-that-is, which has an infinity of attributes. What appear to be individual attributes of things are actually modes of occurrence of the same underlying stuff - All-that-is, God, or Nature. In other words, in a Spinozean world, we can think of things as being distinct without them actually having to be two different substances. For Spinoza, God is "is-ing-ness," the Being force that makes all beings alive and gives the kick of life to "All-that-is."

The natural question is to ask at this point is, "Why go to all this trouble?" What is to be gained in changing a nomenclature? It is still the same stuff, isn't it? The answer is that it is not - or, at least, that such a changed structure necessarily leads to very different interpretations. Spinoza needed to show the internal inconsistency of the apparently well-functioning philosophical system and language of Descartes and his predecessors because he considered it misleading about the way things really were. Spinoza's metaphysics provided him the basis from which to view apparently different and separated things as being not only connected, but also as having the possibility of both a "thinking" and an "extending" aspect - that is, to not only have physical form, but also to have ideational capacity.

A major challenge in reading Spinoza is understanding how, on one hand, Allthat-is can be composed of a single substance, while on the other hand, notions of selfhood can still apply. Spinoza solves many problems with this view by simply denying free will. So what to us appears to be a self-directing individual can be seen, in Spinoza's cosmology, as a part of the determined All-that-is.

But we humans appear to behave, to be motivated, and to perform as individuals. So how can there be actual selves if there is really only one thing that composes every apparent thing? The answer that Spinoza gives to the question, "What is a self?" is contingent upon his metaphysics. This answer affects, in turn, how an individual self 
is able to both consciously participate as a component of All-that-is, and to continue to persist in its being.

In attempting to explain this position, Lloyd (1994) writes, "Cartesian selves are ambiguously located between the individuality of substancehood and the universality of reason. Spinozistic selves rejoin nature through the individuality of bodies construed as uniquely differentiated parts of nature" (p. 3). In other words, in the way in which Spinoza conceives of the human self, it is possible to both see this self as unique - in the way that we, as humans, tend to want to see humans - and to see this self as also ineluctably linked to the rest of nature by virtue of its composition. We are of the same stuff - All-that-is - as is the rest of nature.

My explication of Spinoza's cosmology has been necessarily limited; as well, it is beyond the scope of this paper to thoroughly investigate an Indigenous cosmology, but what I later realized was a very good informal introduction to Spinozean metaphysics came through occasional periods of living with some Anishinaabe elders who had asked me to participate in some work. In their company, I have often heard reference to, not merely a person, but a deer-person, a bear-person, a tree-person. "Person" here, takes the place of "being." In this view, different "persons" appear to be acting as different forms - in Spinoza's terms, modes - of All-that-is. The underlying notion of interconnection is expressed in the common noun "person" that is used for all things. This linguistic shift both reflects and, I think, shapes a worldview that considers different modes of All-that-is as having, if not equal ethical merit, at least an ethical standing. This ethical and ontological standing extends also to the world that we in modern Western culture would not think of as a living one. Thus, the concept of 'rock' is necessarily infused with the notion of its inherent worth or standing as a being. As a mode of being, there is always the potential for an interaction with it. It is also a being that, according to Spinozean cosmology, has both ideational and physical attributes.

Cartesian metaphysics might grant us the simplicity of a world we have come to know, but it comes with a price. In it, thought can exist un-embodied, un-located in an un-contextualized world. It is, and can remain, utterly abstracted and isolated. Spinoza's metaphysics is a complex one, but what we lose in Spinozean complexity we gain in a much richer view of how knowledge is attained and exists in an embodied and interconnected world. So, what Spinoza manages to do is to keep the self as self, but as a self consisting in the same substance and the same thinking as All-that-is. The relevance to a broader notion of cosmopolitanism is evident.

If thinking and extension are aspects of every being that exists in the All-that is, then the integrity of the Anishinaabe perspective mentioned earlier can be better understood. People can do certain things well. For example, we can write lots of words like these, something that other beings cannot do. This might lead us to think of humans as the only beings capable of participating in the attribute of thinking. But in a Spinozean ontology, this would be in error. Despite initial appearances, other modes of being might be able to participate in the attribute of thinking, as well. This is necessarily the case because in Spinoza's cosmos, all beings are of the same stuff, the 
same substance, the same All-that-is. And this substance has the attributes of thinking and extending - that is, what is part of it is both physical and ideational. Any modeany instance of this Being - therefore shares in the capacity for thought and physical extension.

Cartesian metaphysics allows the wholesale instrumental use of beasts; they have no participation in thought, and are incapable of feeling because they are not "thinking things," the characteristic that defines humans. But to extend Spinoza's argument further, in his metaphysics, every being that participates in Being - All-that-is - would have some ethical worth, because Being is equivalent to God. As such, the lightness of an ecological footprint would more accurately signify moral worth than Cartesian rationality. This suggests a different place from which to launch a cosmopolitan project: a place of being, rather than of moral worth established according to principles already human.

The feeling of the pause I take in noting this resembles the kind of pause Appiah's work induces; we are constantly asked, in his discussion of cosmopolitanism, to relocate our own perspectives or ideas on what is moral. In so doing, we are asked to reconsider perspectives we took as commonly agreed. The difference between the project Appiah engages in and Spinoza's is that Spinoza requires us to consider the ethical standing of the more-than-human, inasmuch as it is actually a part of the same substance that composes people. Thus, the notion of the cosmopolis is broadened to include a felt kinship that goes beyond the bounds of the human.

Such a cosmopolis would shift the basis of membership therein from one of responsibility to other moral beings, to one of acting morally in accordance with the capacity one has to formulate moral sensibility. In this view, humans would have high moral obligation. But moral treatment would be based on the quality of participating in being, rather than a human-centred scale that would always tend to favour the human. This position is relevant to certain Indigenous ways of being in the world and ethical stances related to these (Beeman, 2006). But a fuller articulation of these, in the context of a Spinozean cosmology, must wait for another time.

\section{References}

Appiah, K. A. (2006). Cosmopolitanism. New York, NY, and London, England: W. W. Norton and Company.

Beeman, C. (2006). Another way of knowing and being. Doctoral dissertation, Queen's University, Kingston, Canada.

Evernden, N. (1993). The natural alien (2nd ed.). Toronto, Canada: University of Toronto Press.

Held, D. (1999). The transformation of political community: Rethinking democracy in the context of globalization. In I. Shapiro \& C. Hacker-Cordon (Eds.), Democracy's edge. New York, NY: Cambridge University Press.

Johnston, J. S. (2012). Cosmopolitanism and teacher education: Comparing theories. 
Education Letter (Fall/Winter). Kingston, Canada: Queen's University, Faculty of Education.

Lloyd, G. (1994) Part of nature: Self-knowledge in Spinoza's Ethics. Ithaca, NY, and London, England: Cornell University Press.

Lloyd, G. (1996). Spinoza and the Ethics. London, England: Routledge.

Lovelock, J. E. (1972, August 1). Gaia as seen through the atmosphere. Atmospheric Environment (1967), 6(8), 579-580.

Naseem, M. A., and Hyslop-Margison, E. (2006). Nussbaum's concept of cosmopolitanism:

Practical possibility or academic delusion? Paideusis, 15(2), 51-60.

Nussbaum, M. (1994, October 1). Patriotism and cosmopolitanism. Boston Review.

Potts, R. Climate and human evolution. Smithsonian National Museum of History. Accessed

October 18, 2013. http://humanorigins.si.edu/research/climat-research

Spinoza, B. (2002). Collected works of Spinoza. (S. Shirley, Trans.). Indianapolis, IN: Hackett. Toulmin, S. (1990). Cosmopolis. Chicago, IL: University of Chicago Press.

Wienpahl, P. (1979). The radical Spinoza. New York, NY: New York University Press. 